\title{
Costs and Benefits to Phasing Out Paper Currency
}

\section{Citation}

Rogoff, Kenneth S. 2014. Costs and Benefits to Phasing Out Paper Currency. In Volume 29 of NBER Macroeconomics Annual 2014, ed. Jonathan Parker and Michael Woodford. Chicago: University of Chicago Press.

\section{Published Version}

doi:10.3386/w20126

\section{Permanent link}

http://nrs.harvard.edu/urn-3:HUL.InstRepos:12491029

\section{Terms of Use}

This article was downloaded from Harvard University's DASH repository, and is made available under the terms and conditions applicable to Open Access Policy Articles, as set forth at http:// nrs.harvard.edu/urn-3:HUL.InstRepos:dash.current.terms-of-use\#OAP

\section{Share Your Story}

The Harvard community has made this article openly available.

Please share how this access benefits you. Submit a story.

\section{Accessibility}


Presented at NBER Macroeconomics Annual Conference, April 11, 2014

This version May 5, 2014

\section{Costs and benefits to phasing out paper currency \\ By Kenneth Rogoff ${ }^{1}$, Harvard University}

This paper explores the costs and benefits to phasing out paper currency, beginning with large-denomination notes, later extending to all but small coins and bills, and eventually those as well. It is hardly a simple issue; paper currency is deeply ingrained in the public's image of government and country, and any attempt to change long-standing monetary conventions raises a host of complex issues. The symbolic value of the euro, for example, as a flag for nascent European Institutions, is hard to overstate. Nevertheless, it is important to ask whether currency in paper form has outlived its usefulness. Credit and debit cards today are increasingly being used for even small transactions. And although today’s crypto-currencies fall far short of being true currencies - for one thing their prices are simply too volatile - the underlying technologies may ultimately strengthen the menu of electronic payments options. ${ }^{2}$ $\underline{\text { Zero-interest negotiable bonds as an obstacle to negative policy interest rates }}$

\footnotetext{
${ }^{1}$ An earlier draft of this paper formed the basis for a dinner speech at the April 11, 2014, NBER Macroeconomics Conference in Cambridge MA. The author is grateful to Ruth Judson and Stephanie Lo as well as to NBER conference participants for extremely helpful comments, and to Madhusudan Vijay and Diana Zhu for research assistance.

2 The public may use the terms "currency" and "money” interchangeably, but economists do not. Modern central banks typically report several constructs of money, ranging from a narrow one that includes only currency and (electronic) bank reserves at the central bank, to increasingly broad ones that include, for example, transactions deposits at financial institutions (e.g., checking accounts), time deposits, and holdings of shares at money market mutual funds. Currency in the US accounts for roughly $10 \%$ of the Federal Reserve’s main monetary aggregate, M2.
} 
Paper currency has two very distinct properties that should draw our attention. First, it is precisely the existence of paper currency that makes it difficult for central banks to take policy interest rates much below zero, a limitation that seems to have become increasingly relevant during this century. As Blanchard et al. (2010) point out, today's environment of low and stable inflation rates has drastically pushed down the general level of interest rates. The low overall level, combined with the zero bound, means that central banks cannot cut interest rates nearly as much as they might like in response to large deflationary shocks.

If all central bank liabilities were electronic, paying a negative interest on reserves (basically charging a fee) would be trivial. But as long as central banks stand ready to convert electronic deposits to zero-interest paper currency in unlimited amounts, it suddenly becomes very hard to push interest rates below levels of, say, -0.25 to -0.50 percent, certainly not on a sustained basis. Hoarding cash may be inconvenient and risky, but if rates become too negative, it becomes worth it. ${ }^{3}$

In a series of insightful papers, Willem Buiter (2009 and citations therein) has discussed whether it might be possible to find devices for paying negative interest rates on currency. ${ }^{4}$ Buiter notes that there were experiments with stamp taxes during the Great Depression (currency would remain valid only if it were regularly stamped to reflect tax payment). There are a variety of other ideas. For example, Mankiw (2009) points out that the central bank could effectively tax currency by holding lotteries based on serial numbers, and making the "winners" worthless.

\footnotetext{
${ }^{3}$ Of course, central banks can and do impose required reserves at sub-market interest rates as a tax on banks. The problem is when the implied interest rates for depositors turn negative.

${ }^{4}$ Buiter (2009) credits Gesell (1916) as the first to moot the idea of taxing currency.
} 
Paying a negative interest rate on currency, or on electronic reserves at the central bank, may seem barbaric to some. But it is arguably no more barbaric than inflation, which similarly reduces the real purchasing power of currency. The idea of raising target inflation to reduce the likelihood of hitting the zero bound is indeed an alternative approach. Blanchard et al. point out that if central banks permanently raised their target inflation rates from $2 \%$ to $4 \%$, it would leave them scope to make deeper cuts to real interest rates in severe downturns. Arguably, paying negative interest rates is a better approach if, as many believe, inflation becomes more unstable as the general level of inflation rises. Robert Hall (1983) argues forcefully that the central role of monetary policy should be to provide a stable unit of account, and in principle the ability to pay negative interest rates facilitates its ability to achieve this in today's low inflation environment (Hall, 2002, 2012).

Even if there is a good case for allowing the central bank to pay a significant negative interest rate to fight a large deflationary shock, what is to stop a government from using negative interest rates as a wealth tax in normal times? This is a complex issue that parallels many of the problems in trying to design central bank institutions that will resist the temptation to inflate. Nevertheless, the challenges of conducting monetary policy at the zero bound force consideration of alternatives to the status quo. If, as Reinhart and Rogoff (2014) conjecture, business and financial cycles in the $21^{\text {st }}$ century may produce larger fluctuations than they did in the last part of the $20^{\text {th }}$ century, the issue of hitting the zero bound may indeed remain a recurrent one.

$\underline{\text { Anonymous money as a vehicle for facilitating tax evasion and illegal activity }}$ 
We now turn to a second drawback to paper currency. Paper currency facilitates making transactions anonymous, helping conceal activities from the government in a way that might help agents avoid laws, regulations and taxes. This is a big difference from most forms of electronic money that, in principle, can be traced by the government. (We discuss the issue of substitute anonymous transactions vehicles such as Bitcoin, later on.)

Standard monetary theory (e.g., Kiyotaki and Wright 1989) suggests that an essential property of money is that neither buyer nor seller requires knowledge of its history, giving it a certain form of anonymity. (A slight caveat is that the identity of the buyer might be correlated with the probability of the currency being counterfeit, but until now this is a problem that governments have been able to contain.) There is nothing, however, in standard theories of money that requires transactions to be anonymous from tax- or law-enforcement authorities. And yet there is a significant body of evidence that a large percentage of currency in most countries, generally well over 50\%, is used precisely to hide transactions. I have summarized the international evidence in earlier research (Rogoff 1998, 2002). Other than the introduction of the euro, rather little has changed except that, if anything, anonymous currencies have continued to grow at a faster rate than nominal GDP.

Given that banks and businesses are typically quite efficient in their cash management (as evidenced by several central bank surveys), the most surprising fact about currency is the sheer extant amount that most OECD countries have in circulation, far in excess of anything that can be traced to legal use in the domestic economy. Table 1 gives data on currency by denomination and as a share of GDP for the United States, the Eurozone, Japan and Hong Kong. For example, as of March 2013, there was almost 1.3 
trillion dollars in US currency in circulation, or roughly $\$ 4,000$ for every man, woman and child living in the United States. Moreover, nearly $78 \%$ of the total value is in $\$ 100$ bills, meaning more than thirty $\$ 100$ bills per person. By contrast, denominations of $\$ 10$ and under accounted for less than $4 \%$ of the total value of currency in use.

The size of dollar currency holdings, relative to GDP or per capita, is hardly unique. Indeed, in the US the currency supply is 7\% of GDP, in the Eurozone 10\%, and in Japan $18 \%$. Despite having lower per capita income, the Eurozone also has roughly $\$ 4,000$ in euros for every one of its citizen (valued at the April 2014 euro-dollar exchange rate). The euro has a much greater range of high denominations, so the value is not as concentrated in a single denomination as in the United States. Nevertheless, the same basic phenomenon holds, with roughly a third of the value of euro currency held in 50 euro notes (roughly \$70), and another third in 500 euro notes (roughly \$700). Adding in 100 and 200 euro notes brings the percent of high-denomination notes close to that of the US. In Japan, the total amount of currency outstanding is similar to that in the United States and Europe, despite having a population size only $40 \%$ as large. The concentration in the highest denomination is even more acute, with $87 \%$ of the value of notes being in 10,000 yen notes, the largest denomination, roughly $\$ 100$ at April 2014 exchange rates. ${ }^{5}$

It is true that in the case of the US and the euro area, there is fairly convincing evidence that a large share is held abroad. Porter and Judson (1996) use seasonal comparisons with Canada and biometric techniques to infer that roughly $70 \%$ of US currency is held abroad. It should be noted that Canada is a country that has relatively low currency use compared to many other advanced countries. However, the fact that

\footnotetext{
${ }^{5}$ Rogoff $(1998,2002)$ looks at a wide range of OECD countries, and indeed the US does not particularly stand out as having high per capita GDP currency holdings.
} 
currency outstanding is comparable to the US in so many other OECD countries, most of whose currencies are used only domestically, suggests that perhaps the size of currency holdings in the US is similarly quite large; Rogoff (1998) speculates that the ratio of US currency held internationally may be closer to $50 \%$. Of course, as interest rates have fallen to near zero in recent years, it is not surprising that the demand for currency in the domestic US economy appears to have risen; using similar techniques to her earlier work, Judson (2012) estimates around 50\% of US dollars are held domestically post financial crisis. Even if foreign holdings of currency are important for a few countries (including also Hong Kong and Switzerland), this is not thought to be the case for most OECD countries. The Japanese yen does not appear to be a significant international currency.

In any event, it is clear that the long-term trend domestic demand for currency in the legal economy is dwindling, due in part to advances in cashless payments. ${ }^{6}$ As already noted, the small number of central bank surveys that have been performed to measure domestic use of currency in the legal economy typically find very low percentages, on the order of $10-15 \%$ of total extant currency in the case of the United States (see also Feige 2012a, b). Cash is used more intensively in some Eurozone countries. Fischer, Köhler and Seitz (2004) use a wide range of methods to estimate the transactions demand for currency within the euro area to be $25-35 \%$ of total euro currency in circulation. This estimate is broadly in accord with European Central Bank surveys taken after the financial crisis (ECB 2011) that reported holdings and demand for euro in the legal domestic economy of roughly $1 / 3$ of total euros outstanding. Of the remainder, Bartzsch, Rősl and Seitz (2011) look at euro notes issued by the Bundesbank

\footnotetext{
${ }^{6}$ Wang and Wolman (2014) use transaction-level data from a large discount chain to conclude that the cash share of retail sales in the United States will decline by $2.54 \%$ per year.
} 
and find that between 40 and 55\% are held outside of Eurozone countries. (It is quite possible that the overall level of euro notes held outside the Eurozone is lower, since Bundesbank-issued notes are particularly popular, even if in principle all the Eurozone central bank notes should be perfect substitutes.)

Presumably, currency that is not held in the domestic legal economy or in the global economy (legal and underground) is mainly held in the domestic underground economy. ${ }^{7}$ The underground economy includes agents evading taxes, laws and regulation. The size of the underground economy is not known within any precision, though estimates for the US are on the order of $7-10 \%$ of GDP (e.g., IRS 2012, Feige 2012). The IRS estimates that for the benchmark year 2006, the tax gap (tax not paid voluntarily) is over $\$ 450$ billion, with a gap of $\$ 385$ billion still remaining after tax collection efforts. Importantly, this estimate does not include the informal economy (US Treasury Inspector General 2013). In Europe, where taxes are higher and regulation is often more onerous, most estimates suggest that the size of the underground economy is considerably larger than in the US (see Schneider, Buehn and Montenegro 2010).

Summing up, currency should be becoming technologically obsolete. However, in no small part due to its association with the underground economy, it is not.

\section{Arguments against phasing out paper currency}

The arguments for eliminating paper currency are impressive, but there are important points on the other side of the equation. The most straightforward is seigniorage. The United States money supply increased by an average of roughly $\$ 30$

\footnotetext{
${ }^{7}$ It is possible that survey respondents underreport even those cash holdings that are for completely legitimate purposes, for example by individuals who simply do not trust banks. I am implicitly assuming this is the not nearly as important quantitatively as cash holdings used to avoid taxes or to engage in illegal activities.
} 
billion per year from 2002-2007, and averaged roughly $\$ 70$ billion dollars per year in the years immediately following the financial crisis. The magnitudes are similar in many other large advanced countries. If a phase-out of paper currency were simply met by an increased demand for electronic central bank reserves, there would of course be no significant loss. However, precisely because paper currency is anonymous, replacing it with non-anonymous electronic money would likely lead to a large shrinkage in demand, and Treasuries would have to absorb the loss. Rogoff (1998) conjectures that this cost might be fully compensated if a modest fraction of the underground economy is induced to pay taxes, and there are also of course potential gains from reduced law-enforcement costs. It is unclear how easily these activities could substitute into other transactions media, but presumably this could be made difficult by restricting other potential anonymous transactions vehicles.

Of course, if the government simply replaced paper currency with electronic currency that it could somehow credibly make anonymous, there would be not necessarily any long-run shrinkage in demand. The government would continue to garner seigniorage revenues from the underground economy and the problem of the zero bound on nominal interest rates would be effectively eliminated. That said, it is far from clear that the government can credibly issue a fully anonymous electronic currency and even if it could, anonymous electronic fiat money has all the drawbacks of an anonymous paper currency in facilitating tax evasion and illegal activity.

There is also a question of how forcing a more rapid shift to cashless payments would affect transactions costs. Retailers are typically forced to pay a pro-rata fee to companies such as MasterCard and Visa for credit card services. But handling paper 
currency also entails substantial costs to protect against theft and pilferage. Also, in principle, the Federal government could allow individuals to maintain ATMs and debit cards at the Federal Reserve, and arguably these could be serviced by private subcontractors at lower cost than conventional bank services.

Another important argument for maintaining the status quo is that eliminating a core symbol of the monetary regime could disrupt common social conventions for using money, possibly in unexpected ways. For example, it could lead to a precipitous decline in demand for debt and not just for fiat money. This need not happen. In his hugely influential book on monetary policy, Woodford (2003) shows that central bank stabilization policy can work perfectly well in the limit as money's role in transactions goes to zero. As long as social price-setting convention remains, and as long as the central bank can manipulate banks’ reserves to set the price level, monetary stabilization policy can still operate with full force. However, one must be careful that just because a similar equilibrium can obtain with or without a significant transactions role for money, it does not necessarily mean that private agents will focus on the same equilibrium as they would when there exists paper currency. Yes, the government can help coordinate expectations by insisting that taxes are paid in the electronic fiat currency, and that all state contracts be denominated in this currency. But it is important to acknowledge that there is a least an outside risk that if the government is too abrupt is abandoning a century-old social convention, it will destabilize inflation expectations, introduce a risk premium into bond pricing, and generally induce unexpected macroeconomic instabilities. 
There is also a potential risk to central bank independence. Even if eliminating currency is at least revenue neutral for the government as a whole, the central bank is the one that will lose seigniorage revenue. The Treasury is the one that will correspondingly gain through higher tax revenues and lower law-enforcement costs. Under longstanding institutional relationships, the ability to self-finance has put central banks in a privileged position. Although governments typically maintain oversight of central bank budgets, the fact that the central bank nominally appears to be a "profit center" considerably strengthens its hand in maintaining operational independence. In recent years, quantitative easing has been a massive money maker, but this is not the normal state of affairs when currency provision is a key source of revenue.

Another argument for maintaining paper currency is that it pays to have a diversity of technologies and not to become overly dependent on an electronic grid that may one day turn out to be very vulnerable. Paper currency diversifies the transactions system and hardens it against cyber attack, EMP blasts, etc. This argument, however, seems increasingly less relevant because economies are so totally exposed to these problems anyway. With paper currency being so marginalized already in the legal economy in many countries, it is hard to see how it could be brought back quickly, particularly if ATM machines were compromised at the same time as other electronic systems. $^{8}$

A different type of argument against eliminating currency relates to civil liberties. In a world where society’s mores and customs evolve, it is important to tolerate experimentation at the fringes. This is potentially a very important argument, though the

\footnotetext{
8 It is true that nearly all disaster-preparedness instructions recommend holding cash, though unless individuals are following this advice, there would still need to be a mechanism for distributing currency after a catastrophe.
} 
problem might be mitigated if controls are placed on the government's use of information (as is done say with tax information), and the problem might also be ameliorated if small bills continue to circulate. ${ }^{9}$

Last but not least, if any country attempts to unilaterally reduce the use of its currency, there is a risk that another country's currency would be used within domestic borders. Even if that risk is not great for a country like the United States, there is still the loss of revenue from foreign users of currency (many of whom may be engaged in underground or illegal activities within their own borders, even if not within US borders). ${ }^{10}$ Thus, any attempt to eliminate large-denomination currency would ideally be taken up in a treaty that included at the very least the major global currencies.

\section{$\underline{\text { Conclusions }}$}

Paper currency came into prominent worldwide use at the time of World War I, and has played a major role in shaping the global history of the last 100 years. Despite huge and ongoing technological advances in electronic transactions technologies, it has remained surprisingly durable, even if its major uses seem to be buried in the world underground and illegal economy. With many central banks now near or at the zero interest rate bound, there are increasingly strong arguments for exploring how it might be phased out of use. True, there are many arguments for not disturbing the status quo,

\footnotetext{
${ }^{9}$ I am implicitly assuming that if only small bills remain in circulation, the central bank would still have the practical capacity to lower interest rates to significantly more negative levels than if large bills continue to circulate, since hoarding costs are much greater for any large sum.

10 Obviously, some foreign use of dollar and euro currency is beneficial to the local economies, even if a significant share goes to facilitating illegal and underground activities. Thus, some countries may consider it detrimental to their interests to see phasing out of dollar and euro paper currency. However, in an era where inflation rates in most countries have fallen radically over the past two decades (making local currencies more attractive), the benefits of being able to use dollar and euro paper currency in the legal economy has presumably been falling, and will continue to do so.
} 
ranging from the importance of seigniorage revenues to civil liberties arguments. Given relentless technological advance, embodied in everything from mobile banking to crytocurrencies, we may already live in the twilight of the paper currency era anyway, Nevertheless, given the role of paper currency (especially large-denomination notes) in facilitating tax evasion and illegal activity, and given the persistent and perhaps recurring problem of the zero bound on nominal interest rates, it is appropriate to consider the costs and benefits to a more proactive strategy for phasing out the use of paper currency.

\section{$\underline{\text { References }}$}

Bartzsch, Nikolaus, Gerhard Rösl and Franz Seitz. 2011. “Foreign Demand for Euro Banknotes Issued in Germany.” Deutsche Bundesbank Monthly Report (January).

Blanchard, Olivier, Giovanni Dell'Ariccia and Paolo Mauro. 2010. "Rethinking Macroeconomic Policy.” IMF Position Note, SPN/10/03 (February 12).

Buiter, Willem H. 2009. "Negative Nominal Interest Rates: Three Ways to Overcome the Zero Lower Bound.” NBER Working Paper 15118 (June).

Buiter, Willem H. and Nikolaos Panigirtzoglou. 2003. “Overcoming the Zero Bound on Nominal Interest Rates with Negative Interest on Currency: Gesell's Solution.” Economic Journal 113, no. 490 (October): 723-746.

European Central Bank. 2011. "The Use of Euro Banknotes - Results of Two Surveys among Households and Firms,” ECB Monthly Bulletin (April): 79-90.

Feige, Edgar L. 2012a. “The Myth of the “Cashless Society”: How much of America’s currency is overseas?” University Library of Munich, MPRA paper 42169. 
Feige, Edgar L. 2012b. “New Estimates of U.S. Currency Abroad, the Domestic Money Supply and the Unreported Economy.” Crime, Law and Social Change 57, no. 3 : 239-263 .

Fischer, B., P. Köhler and F. Seitz. 2004. "The Demand for Euro Currencies, Past, Present and Future,” ECB Working Paper Series 330 (April).

Gesell, Silvio. 1916. Die Natuerliche Wirtschaftsordnung. Rudolf Zitzmann Verlag. Available in English as The Natural Economic Order. Peter Owen Ltd., London, 1958.

Hall, Robert E. 1983. “Optimal Fiduciary Monetary Systems.” Journal of Monetary Economics 12, no. 1: 33-50.

Hall, Robert E. 2002. “Controlling the Price Level.” Contributions to Macroeconomics 2, no. 1: Article 5.

Hall, Robert E. 2013. “The Routes into and out of the Zero Lower Bound.” Paper presented at the Kansas City Federal Reserve Economic Policy Symposium on Global Dimensions of Unconventional Monetary Policy. Jackson Hole, Wyoming (August 22-24).

Internal Revenue Service. 2012. “IRS Releases 2006 Tax Gap Estimates.” FS-2012-6: http://www.irs.gov/uac/IRS-Releases-2006-Tax-Gap-Estimates (January).

Internal Revenue Service. 2012. “IRS Releases New Tax Gap Estimates; Compliance Rates Remain Statistically Unchanged from Previous Study.” IR-2012-4: http://www.irs.gov/uac/IRS-Releases-New-Tax-Gap-Estimates;-ComplianceRates-Remain-Statistically-Unchanged-From-Previous-Study (January 6). 
Judson, Ruth. 2012. “Crisis and Calm: Demand for U.S. Currency at Home and Abroad from the Fall of the Berlin Wall to 2011.” International Finance Discussion Paper 2012-1058, Board of Governors of the Federal Reserve System. Washington, DC (November).

Mankiw, N. Gregory. 2009. “It May Be Time for the Fed to Go Negative.” New York Times (April 18).

Kiyotaki, Nobuhiro and Randall Wright. 1989. “On Money as a Medium of Exchange.” The Journal of Political Economy 87, no. 4 (August): 927-954.

Porter, Richard D. and Ruth Judson. 1996. “The Location of US Currency: How Much Is Abroad?” Federal Reserve Bulletin (October).

Reinhart, Carmen M, and Kenneth S Rogoff. 2014. "Recovery from Financial Crises: Evidence from 100 Episodes,” forthcoming American Economic Association Papers and Proceedings (May).

Rogoff, Kenneth S. 1998. "Foreign and Underground Demand for Euro Notes: Blessing or Curse?" Economic Policy 26 (April): 263-303.

Rogoff, Kenneth S. 2002. “The Surprising Popularity of Paper Currency.” Finance and Development 39, no. 1: (March).

Schneider, Friedrich, Andreas Buehn and Claudio E. Montenegro. 2010. "New Estimates for the Shadow Economies all over the World.” International Economic Journal 24 (December): 443-461.

Treasury Inspector General for Tax Administration. 2013. “The Internal Revenue Service Needs to Improve the Comprehensiveness, Accuracy, Reliability, and Timeliness of the Tax Gap Estimate.” Reference Number: 2013-IE-R008 (August 21). 
Wang, Zhu and Alexander L. Wolman. 2014. "Payment Choice and the Future of

Currency: Insights from Two Billion Retail Transactions.” Federal Reserve Bank

of Richmond Working Paper No. 14-09 (April).

Woodford, Michael. 2003. Interest and Prices; Foundations of a Theory of Monetary

Policy. Princeton and Oxford: Princeton University Press.

Table 1

\begin{tabular}{|c|c|c|c|}
\hline \multicolumn{5}{|c|}{ EUROPE } \\
\hline \multicolumn{3}{|c|}{ Currency in circulation - February 20, 2014 } \\
\hline Denomination & Value (in thousands of euros) & Value (\% of total currency) & Value (\% of 2013 GDP) \\
\hline$€ 5$ & $€ 8,028,790.8$ & $0.838 \%$ & $0.084 \%$ \\
\hline$€ 10$ & $€ 20,115,075.4$ & $2.100 \%$ & $0.210 \%$ \\
\hline$€ 20$ & $€ 57,254,121.0$ & $5.978 \%$ & $0.598 \%$ \\
\hline$€ 50$ & $€ 335,791,854.3$ & $35.063 \%$ & $3.507 \%$ \\
\hline$€ 100$ & $€ 183,322,233.0$ & $19.142 \%$ & $1.915 \%$ \\
\hline$€ 200$ & $€ 39,428,190.4$ & $4.117 \%$ & $0.412 \%$ \\
\hline$€ 500$ & $€ 289,720,996.0$ & $30.252 \%$ & $3.026 \%$ \\
\hline Total (banknotes) & $€ 933,661,260.8$ & $\mathbf{9 7 . 4 9 1 \%}$ & $\mathbf{9 . 7 5 2 \%}$ \\
\hline All coins & $€ 24,029,083.2$ & $2.509 \%$ & $0.251 \%$ \\
\hline Total (incl. coins) & $€ 957,690,344.0$ & $100 \%$ & $10.003 \%$ \\
\hline
\end{tabular}

Sources: http://www.ecb.europa.eu/stats/euro/circulation/html/index.en.html and

http://sdw.ecb.europa.eu/browseSelection.do?DATASET=0\&sfl1=3\&sfl2=4\&REF_AREA=308\&sfl3=4\&BKN_ITEM=NC10\&node= $\underline{5274891}$

\begin{tabular}{|c|c|c|c|}
\hline \multicolumn{3}{|c|}{ HONG KONG } \\
\hline \multicolumn{3}{|c|}{ Currency in circulation - end 2012 } \\
\hline Denomination & Value (in billions of HKD) & Value (\% of total currency) & Value (\% of 2012 GDP) \\
\hline HK\$10 & HK\$2.92 & $0.967 \%$ & $0.143 \%$ \\
\hline HK\$20 & HK\$11.38 & $3.773 \%$ & $0.558 \%$ \\
\hline HK\$50 & HK\$7.00 & $2.322 \%$ & $0.344 \%$ \\
\hline HK\$100 & HK\$27.13 & $8.998 \%$ & $1.332 \%$ \\
\hline HK\$500 & HK\$74.09 & $24.574 \%$ & $3.637 \%$ \\
\hline HK\$1,000 & HK\$169.19 & $56.115 \%$ & $8.305 \%$ \\
\hline Total (banknotes) & HK\$291.70 & $\mathbf{9 6 . 7 5 0 \%}$ & $\mathbf{1 4 . 3 1 9 \%}$ \\
\hline All coins & HK\$9.80 & $3.250 \%$ & $0.481 \%$ \\
\hline Total (incl. coins) & HK\$301.50 & $\mathbf{1 0 0 \%}$ & $\mathbf{1 4 . 8 0 0 \%}$ \\
\hline
\end{tabular}

Source: http://www.hkma.gov.hk/media/eng/publication-and-research/annual-report/2012/11_Monetary Stability.pdf (page 50) 
Table 1 continued

\begin{tabular}{|c|c|c|c|}
\hline \multicolumn{3}{|c|}{ JAPAN } \\
\hline \multicolumn{3}{|c|}{ Currency in circulation - February 2014 } \\
\hline Denomination & Value (in 100 millions of yen) & Value (\% of total currency) & Value (\% of 2013 GDP) \\
\hline$¥ 500$ & $¥ 1,066$ & $0.118 \%$ & $0.022 \%$ \\
\hline$¥ 1,000$ & $¥ 38,036$ & $4.193 \%$ & $0.795 \%$ \\
\hline$¥ 2,000$ & $¥ 1,995$ & $0.220 \%$ & $0.042 \%$ \\
\hline$¥ 5,000$ & $¥ 29,595$ & $3.262 \%$ & $0.619 \%$ \\
\hline$¥ 10,000$ & $¥ 790,196$ & $87.101 \%$ & $16.519 \%$ \\
\hline Total (banknotes) & $¥ 861,335$ & $\mathbf{9 4 . 9 4 2 \%}$ & $\mathbf{1 8 . 0 0 6 \%}$ \\
\hline All coins & $¥ 45,884$ & $5.058 \%$ & $0.959 \%$ \\
\hline Total (incl. coins) & $¥ 907, \mathbf{2 2 0}$ & $\mathbf{1 0 0} \%$ & $\mathbf{1 8 . 9 6 5 \%}$ \\
\hline
\end{tabular}

Source: http://www.stat-search.boj.or.jp/index en.html

\begin{tabular}{|c|c|c|c|}
\hline \multicolumn{3}{|c|}{ UNITED STATES } \\
\hline \multicolumn{3}{|c|}{ Currency in circulation - December 31, 2013 } \\
\hline Denomination & Value (in billions of dollars) & Value (\% of total currency) & Value (\% of 2013 GDP) \\
\hline$\$ 1$ & $\$ 10.6$ & $0.885 \%$ & $0.063 \%$ \\
\hline$\$ 2$ & $\$ 2.1$ & $0.175 \%$ & $0.013 \%$ \\
\hline$\$ 5$ & $\$ 12.7$ & $1.060 \%$ & $0.076 \%$ \\
\hline$\$ 10$ & $\$ 18.5$ & $1.544 \%$ & $0.110 \%$ \\
\hline$\$ 20$ & $\$ 155.0$ & $12.935 \%$ & $0.923 \%$ \\
\hline$\$ 50$ & $\$ 74.5$ & $6.217 \%$ & $0.443 \%$ \\
\hline$\$ 100$ & $\$ 924.7$ & $77.168 \%$ & $5.504 \%$ \\
\hline$\$ 500$ to $\$ 10,000$ & $\$ 0.3$ & $0.025 \%$ & $0.002 \%$ \\
\hline Total & $\$ 1,198.3$ & $100 \%$ & $7.133 \%$ \\
\hline
\end{tabular}

Source: http://www.federalreserve.gov/paymentsystems/coin_currcircvalue.htm 